\title{
Influenza vaccination in the elderly
}

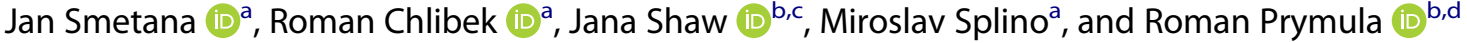 \\ a University of Defence, Faculty of Military Health Sciences, Hradec Kralove, Czech Republic; ${ }^{b}$ University of Hradec Kralove, Faculty of Science, Hradec \\ Kralove, Czech Republic; 'SUNY Upstate Medical University, Department of Pediatrics, Division of Pediatric Infectious Diseases, Syracuse, NY, USA; \\ ${ }^{\mathrm{d}}$ Charles University, Faculty of Medicine in Hradec Kralove, Department of Social Medicine, Hradec Kralove, Czech Republic
}

\begin{abstract}
Seasonal influenza is a prevalent and serious annual illness resulting in widespread morbidity and economic disruption throughout the population; the elderly and immunocompromised are particularly vulnerable to serious sequelae and mortality. The changing demographics worldwide to an aging society have important implications for public health policy and pharmaceutical innovations. For instance, primary prevention via immunization is effective in reducing the burden of influenza illness among the elderly. However, the elderly may be insufficiently protected by vaccination due to the immunosenescence which accompanies aging. In addition, vaccine hesitancy among the younger populations increases the likelihood of circulating infectious diseases, and thus concomitant exposure. While it is clear that the development of more immunogenic vaccines is an imperative and worthy endeavor, clinical trials continue to demonstrate that the current influenza vaccine formulation remains highly effective in reducing morbidity and mortality when well matched to circulating strains.
\end{abstract}

\section{ARTICLE HISTORY}

Received 27 February 2017

Revised 25 May 2017

Accepted 13 June 2017

\section{KEYWORDS}

burden of flu; elderly; efficacy; influenza vaccination; immunization strategies

\section{Introduction: Why is influenza immunization a critical public health issue?}

Influenza is an acute and highly contagious viral infection with global circulation. The influenza "season" is a period of $8-10$ weeks during which $80 \%$ of influenza outbreaks occur, with the specific timeframe varying depending on region but typically from late autumn to early spring in temperate areas of both hemispheres. ${ }^{1}$ These seasonal epidemics are caused by the pathogen's frequent antigenic drifts, which also serve as the virological driver for annual vaccine development and deployment. ${ }^{2,3}$

The influenza virus causes an acute febrile illness with a severity that ranges from mild to extremely serious, in some cases resulting in mortality. Seasonal influenza is typically characterized by a sudden onset of fever, cough, headache, muscle and joint pain, severe malaise and sore throat. Most people recover from infection without sequelae within 1-2 weeks without requiring special medical attention. During a typical influenza season a high proportion of the population is estimated to be clinically asymptomatic. ${ }^{4}$ Those at highest risk for a clinically serious course of infection are children under $5 \mathrm{y}$ of age, the elderly, pregnant women and persons with underlying chronic medical conditions. ${ }^{5}$ The morbidity accompanying influenza is associated with concomitant increases in health care utilization, such as outpatient medical visits, hospitalization, and mortality, particularly among high-risk groups.

The World Health Organization (WHO) estimates that influenza annually infects about $5-15 \%$ of the population. The estimated annual global burden of influenza is nearly 1 billion individuals infected, 3 to 5 million cases of severe disease, and
250000 to 500000 deaths. Most influenza-associated deaths in developed countries occur among elderly persons $65 \mathrm{y}$ of age or older. ${ }^{6}$ According to European Center for Disease Prevention and Control (ECDC) data, seasonal influenza annually causes 40 to 50 million symptomatic cases in the European Union (EU)/European Economic Area (EEA), and 15 000-70 000 persons die of influenza sequelae. ${ }^{7}$

The primary goal of vaccination is the prevention of serious infections, complications, hospitalizations, and deaths; this is especially important among high risk groups such as the elderly. Improved influenza vaccination coverage among the general population will enhance the effectiveness of vaccination by reducing circulating disease and thereby lessening the socioeconomic impact of infection. For decades, the majority of developed countries have recommended influenza vaccination for the elderly, and this recommendation is expanding to developing nations as well. Recently, however, this recommendation has been criticized based on a perception of poor efficacy. With this in mind, we review the data regarding morbidity and mortality as well as vaccine effectiveness (a concept which differs importantly from efficacy) and suggest that there continues to be a solid rationale supporting vaccination for the elderly. We also recognize that certain virological and biologic realities limit the effectiveness of the vaccine, points which will be reviewed here. Yet despite these limitations, development of a more robust vaccine to better serve the elderly has important collateral benefits for the population as a whole, and the endeavor merits a rigorous attention to the science as well as the strategies to promote and protect the public health. 


\section{Burden of influenza in elderly (65+ years of age)}

While influenza is highly infectious, the health impact of active infection is not uniformly distributed. Various factors are important, such as susceptibility to circulating virus, age, and underlying medical conditions. For healthy adults, seasonal influenza generally does not cause severe infection, but for the elderly, infection is a serious health concern. The risk of influenza-related mortality increases sharply after $65 \mathrm{y}$ of age. ${ }^{8,9,10}$

The higher prevalence of comorbidities among the elderly increases the risk and severity of influenza in this age group. While infection is generally surmountable among healthy adults under $50 \mathrm{y}$ of age, influenza remains an important cause of outpatient medical visits and lost productivity. In the elderly, complication rates are elevated and medical care, including inpatient hospitalizations, are needed. ${ }^{11}$

The impact of influenza varies widely from year to year, and the annual increase in hospitalizations and deaths observed during winter influenza season is relatively predictable. However, it is difficult to attribute the specific burden of influenza due to co-circulation of influenza viruses with other respiratory pathogens (e.g. respiratory syncytial virus). ${ }^{12}$ Secondly, diagnosis is often based only on the clinical manifestation of influenza-like illness but without specific laboratory confirmation. ${ }^{13}$

Despite these challenges, estimates of the burden of disease among the elderly are important for developing effective influenza vaccination strategies, preventive measures and clinical treatments. ${ }^{14}$ A United States (US) Centers for Disease Control and Prevention (CDC) analysis from 2010 estimated that influenza-associated deaths among all age groups with underlying respiratory and circulatory conditions (including pneumonia and influenza infection) ranged from 3349 to 48614 annually during the seasonal influenza periods $1976-1977$ to 2006-2007; deaths attributable solely to pneumonia or influenza during the same period were much lower (961 to 14 715). Among the elderly (adults aged $\geq 65$ years), the estimated influenza-associated deaths with underlying respiratory and circulatory conditions ranged from 2344 to 43727 annually, while those attributable solely to pneumonia or influenza were in the range 673 to 13245 annually.

A cursory review of the US data illustrates the importance of vigilance in protecting the elderly: during this period, deaths among persons aged $\geq 65 \mathrm{y}$ accounted for $89.4 \%$ of the overall estimated average annual influenza-associated deaths with underlying respiratory and circulatory causes. This analysis also indicated the variation in the estimated number of deaths from season to season and its close relation to circulated influenza virus. ${ }^{15}$ The subsequent modeling analysis of populationbased surveillance data in the US covering seasons from the 2010-11 to the 2012-13 described poor detection of influenzarelated hospitalizations. The analysis estimated that $54-70 \%$ of hospitalizations and $71-85 \%$ of deaths occurred among adults aged $\geq 65 \mathrm{y}^{16}$

A study conducted in Israel evaluated age-specific mortality during the influenza season from 1999-2006. Overall mortality rates in this study ranged from 7.7 to 36.1 / 100000 for all causes, and from 4.4 to $24.4 / 100000$ for respiratory and circulatory causes. Influenza-associated deaths from respiratory and circulatory diseases ranged from $280-1516$ annually; importantly, about $90 \%$ of deaths were among persons $65 \mathrm{y}$ or older while only about $1 \%$ occurred among those younger than $50 \mathrm{y} .{ }^{17}$

\section{Influenza - Health economics}

In addition to health impact, the influenza has also an important economic impact. Economic data are an essential part for effective decision of policy makers but estimating the economic impact of influenza is complicated. Direct (outpatient visit and hospitalization costs, drug consumptions etc.) and indirect costs (work absenteeism, productivity lost etc.) should be included. Because of age and underlying medical conditions, the elderly are in higher risk of influenza complications development. Hand in hand, the high proportion of influenza related costs could be found in older people. The study of annual impact of seasonal influenza in the US based on 2003 US population estimated average total economic burden $\$ 87.1$ billion and direct medical costs $\$ 10.4$ billion. From point of view of elderly people it was important that of the total economic burden of influenza $64 \%$ was borne by people aged $\geq 65 \mathrm{y}$. Approximately $40 \%$ of direct medical costs were used on treatment of elderly in this age group. ${ }^{18}$ The cost of influenza in France was estimated to total $€ 2.1$ billion in 1989 and on the basis of 1997 German Sickness Funds, the costs of influenza were $€ 1$ billion. ${ }^{19}$ The estimated costs of seasonal epidemics from $1999-2008$ in Italy ranged from $€ 15$ to $€ 20$ billion. $^{20}$ Study from Norway assessed influenza seasons from 1998 to 2006. The direct medical cost of seasonal influenza achieved US\$22 million annually. Indirect costs significantly exceeded direct costs. The annual estimated productivity loss was calculated to US $\$ 231$ million. Self-reported sick leave accounted for approximately one-third of the total indirect cost and represented important part of the economic burden. ${ }^{21}$

The results of studies shew great economic burden of influenza generally and in elderly especially.

Immunization could effectively reduce the annual economic burden of influenza. Cost-effectiveness of vaccination programs depends on a lot of variables. Vaccine strain, disease severity level, matching of vaccine circulating strains, vaccine efficacy etc. should be counted. Studies of economic evaluation of influenza vaccination were conducted in different countries. There are however remarkable differences in the methodologies for estimating economic burden and costs and also outcome varies. $^{22,23,24,25,26,27}$ Generally, it could be stated that current influenza vaccination programmes are able to reduce disease burden and show cost-effectiveness for elderly aged $\geq 65 \mathrm{y}$. The savings created from reduced health care costs and indirect savings can offset the cost of vaccination programmes.

\section{Immune response to infection in the elderly}

With advancing age, the innate and adaptive immune responses gradually deteriorate, manifesting in a reduced capacity to respond to infection and immunization. Vaccine immunogenicity is defined as "the strength or magnitude of an immune response." 28 Vaccine efficacy and effectiveness measure the proportionate reduction in cases among vaccinated persons either under ideal or field conditions, respectively. ${ }^{29,30}$ 
The elderly typically experience a vaccine-induced immunogenicity of only $30-40 \% .^{31}$ Immunosenescence is increasingly being viewed less as an overall deterioration in response but rather a remodeling of the immune system which results in dysregulation of various components; some functions deteriorate while others remain unchanged or overreact (as in autoimmune disorders). ${ }^{32}$

\section{Innate response}

With aging, the initial innate response by neutrophils and macrophages is marked by reduced phagocytic activity and a diminished oxidative burst. ${ }^{33}$ Toll-like receptors (TLRs), transmembrane proteins on phagocytic cells, provide an important conduit between the innate and adaptive responses by recognizing non-self proteins and triggering the intracellular signaling pathways which mediate the antigen-specific response. ${ }^{34}$ In the macrophages of elderly persons, defects in TLR expression impair this critical response. ${ }^{35}$ Additionally, epithelial cells provide an important structural and immune barrier to pathogens, however, the number of Langerhans' cells in the skin declines with age. ${ }^{36}$ Together, these age-related disruptions in the innate immune response reduce the amount of antigen uptake at the injection site and diminish vaccine immunogenicity.

\section{Adaptive response}

The adaptive response depends on the rapid recognition of foreign antigens and is mediated by antigen-presenting proteins found in cell membranes, such as the major histocompatibility complex (MHC) class I and II cells. The MHC class I complexes in the membranes of nucleated cells interact with cytotoxic T cells; the MHC class II proteins in antigen-presenting cells (e.g., B cells, macrophages and dendritic cells) primarily interact with helper T cells. The MHC class II cells present antigen fragments on the cell surface to CD4+ T lymphocytes, but upregulation of these cells is impaired by aging. Both animal models and human studies have demonstrated reductions in antigen presentation by dendritic cells. ${ }^{37,38,39,40,41,42,43}$

\section{Impact on vaccine efficacy}

An efficient immune response depends on functional cell signaling pathways to coordinate the complex interactions between innate and adaptive immune systems. Impaired processing and presentation of antigens diminishes the immune response in the elderly. ${ }^{44}$ The cellular pathways disrupted by aging include migration of antigen presenting cells, antigen presentation by dendritic cells, and cytokine production. Markers of poor antibody recruitment include decreased IgA and IgG concentrations, delays in achieving peak titers, and a rapid decline in antibody concentrations. Among those aged $\geq$ 75 years, influenza seroprotection is only 29-46\%, compared with $41-58 \%$ among those $60-74$ y of age. ${ }^{45}$ Additionally, a shift from proinflammatory Th1 cytokines to the more antiinflammatory Th2 cytokines may be correlated with reduced cytotoxic $\mathrm{T}$ lymphocyte (CTL) response, and an impaired response to influenza vaccine. ${ }^{46}$ The reduced humoral responses are believed to be due to the dysfunction of helper naive, aged $\mathrm{CD}^{+} \mathrm{T}$ cells ${ }^{47}$ and reduced follicular $\mathrm{T}$ cell support. $^{48}$

Although specific $\mathrm{T}$ cell responses are impaired in the elderly, CTL recruitment may serve as a better proxy for protection against influenza than a simple measure of antibody concentrations. ${ }^{49}$

\section{Immunization strategies around the world}

Influenza is a vaccine-preventable disease. The first influenza vaccines have been developed, tested and used in the 1930s and 1940s, and in Europe since 1960s. ${ }^{50,51,52,53}$ Vaccines are registered and licensed for use in the elderly as trivalent or quadrivalent, with and without adjuvant. Trivalent influenza vaccines contain an $\mathrm{A}(\mathrm{H} 1 \mathrm{~N} 1)$-like influenza virus, an $\mathrm{A}$ (H3N2)-like influenza virus and a B-like influenza virus. The MF59 adjuvanted trivalent inactivated influenza vaccine is licensed for persons aged $\geq 65$ y of age. Quadrivalent vaccines include an additional vaccine virus strain, a B-like virus. The World Health Organization (WHO) provides recommendations in February and September each year regarding which viruses will be included in influenza vaccines for the forthcoming northern and southern hemisphere influenza seasons, respectively. No preferential recommendation is made for one influenza vaccine product over another for persons for whom more than one licensed. For persons aged $65 \mathrm{y}$ and older any registered influenza vaccine, standarddose or high-dose, trivalent or quadrivalent, unadjuvanted or adjuvanted could be used for immunization. ${ }^{54}$ Practically speaking, however, not all registered influenza vaccines are available every year; fluctuations in production and distribution often limit the options. The list of approved influenza vaccines is shown in Table 1 .

Notwithstanding the potential for supply issues, several vaccination strategies effectively prevent influenza when deployed in a population-based manner. Generally, immunization programs first seek to protect the most vulnerable persons, older adults and all persons (over 6 months of age) with a chronic medical condition. The secondary strategy is to vaccinate healthy children, adolescent and adults to limit disease circulation. In addition, employers often encourage influenza immunisation of their staff (for example health care workers and military personnel). Additional high-risk groups, such as pregnant women, are added to the multi-pronged approach as evidence accumulates. In 2012, the WHO Strategic Advisory Group of Experts (SAGE) recommended pregnant women as the most important high risk group for inactivated seasonal influenza vaccination. If not already doing so, countries with existing influenza vaccination programs should incorporate the immunization of pregnant women. ${ }^{55}$ Influenza vaccine should also be recommended as an integral part of cardiovascular disease management and prevention in the elderly. This strategy is based on results of observational and clinical trials results showing an impressive 15-40\% efficacy of influenza vaccine in preventing acute myocardial infarction. ${ }^{56}$ This range of efficacy compares favourably with the accepted routine coronary prevention measures such as smoking cessation (32-43\%), statins $(19-30 \%)$ and antihypertensive therapy $(17-25 \%){ }^{57}$ In summary, the following additional risk groups should be 
Table 1. Influenza vaccines licensed for elderly in the European Union and United States.

\begin{tabular}{|c|c|c|c|}
\hline Flu Vaccine (Tradename) & Vaccine Type & Age recommended & Manufacturer \\
\hline \multicolumn{4}{|l|}{ Vaccines Licensed for Use in the European Union ${ }^{1}$} \\
\hline Vaxigrip & Inactivated, adjuvanted, trivalent & 6 months and older & Sanofi Pasteur \\
\hline Fluarix & Inactivated, trivalent & 6 months and older & GlaxoSmithKline \\
\hline Fluarix Tetra & Inactivated, quadrivalent & 3 y and older & GlaxoSmithKline \\
\hline Fluad & Inactivated, adjuvanted, trivalent & 65 y and old & Novartis \\
\hline Fluvirin & Inactivated, trivalent & $4 \mathrm{y}$ and older & Novartis \\
\hline Influvac & Inactivated, trivalent & 6 months and older & BGP Products B.V. \\
\hline Foclivia & Inactivated, adjuvanted, monovalent (H5N1) & $18 \mathrm{y}$ and older & Seqirus \\
\hline Aflunox & Inactivated, adjuvanted, monovalent (H5N1) & $18 \mathrm{y}$ and older & Seqirus \\
\hline \multicolumn{4}{|l|}{ Vaccines Licensed for Use in the United States ${ }^{2}$} \\
\hline Fluad & Inactivated, adjuvanted, trivalent & $65 \mathrm{y}$ and older & Seqirus \\
\hline Afluria & Inactivated, trivalent & 5 y and older & Seqirus \\
\hline Fluarix quadrivalent & Inactivated, quadrivalent & $3 y$ and older & GlaxoSmithKline \\
\hline Fluvirin & Inactivated, trivalent & $4 \mathrm{y}$ and older & Seqirus \\
\hline Agriflu & Inactivated, trivalent & $4 \mathrm{y}$ and older & Novartis \\
\hline Fluzone High Dos & Inactivated, trivalent & 65 y and older & Sanofi Pasteur \\
\hline Fluzone quadrivalent & Inactivated, quadrivalent & 6 months and older & Sanofi Pasteur \\
\hline Flucelvax & Inactivated, trivalent & $4 y$ and older & Seqirus \\
\hline Flublok & Inactivated, trivalent & $18 \mathrm{y}$ and older & Protein Science Corporation \\
\hline Flublok Quadrivalent & Inactivated, quadrivalent & $18 \mathrm{y}$ and older & Protein Science Corporation \\
\hline Influenza Virus Vaccine H5N1 (no Trade Name) ${ }^{3}$ & Inactivated, adjuvanted, monovalent & $18 \mathrm{y}$ and older & Sanofi Pasteur \\
\hline
\end{tabular}

${ }^{1}$ Approved by European Medicine Agency (EMA)

${ }^{2}$ Approved by Food and Drug Administration (FDA)

${ }^{3}$ Only for National Stockpile

considered, in no specific priority order: health-care workers, children aged 6-59 months, and adults with high risk health conditions.

The immune response to vaccination is reduced in the elderly compared with young, healthy adults. ${ }^{58}$ The duration of protection after influenza vaccination in the elderly is unclear. Increasing evidence demonstrates that influenza vaccines may be less effective in the elderly than in younger adults. A decrease in vaccine effectiveness during the winter season has been reported from surveillance studies in some countries and a decline in effectiveness was most significant in people over $65 \mathrm{y}$ of age. ${ }^{59,60} \mathrm{~A}$ meta-analysis of evidence for the year-round persistence of vaccine-induced antibody following trivalent, inactivated, seasonal influenza vaccination in the elderly described the decline from Day 21-42 to 360, in geometric mean titres of specific antibodies and the proportion of seroprotected subjects. The authors suggest that clinical protection does not persist year-round in the elderly. ${ }^{61}$ Describing the true duration of post-vaccination protection is important for countries with biannual epidemics of influenza.

Despite methodological discrepancies among the meta-analyses of seasonal vaccines for the elderly, most influenza vaccines show statistically significant efficacy within a highly variable range. This variation underlies the controversy about immunization strategies for older adults. ${ }^{62,63,64}$ Nevertheless, elderly persons are at high risk of severe disease and mortality associated with influenza and they remain the central focus of influenza vaccine strategies in many countries to reduce complications, hospitalizations and mortality. The WHO and the ECDC agree that targeting the elderly, defined as those age $65 \mathrm{y}$ or more, is a sound strategy to prevent adverse outcomes from influenza. ${ }^{65,66}$ Many countries thus recommend annual influenza vaccination for the elderly ${ }^{67}$ and high risk groups such as those with underlying medical conditions and pregnant women. ${ }^{68}$ In some countries, vaccination of the elderly has been a vanguard of public health practice for decades, since the 1960s in the US. Immunization strategy has thus been under evaluation and development for many years ${ }^{69}$ and recommendations for influenza vaccination vary by country and season, examples of which are reviewed in Table 2.

No universal set of recommendations prescribes the definition of "older age" groups. Many countries use age $65 \mathrm{y}$ as a criterion, whereas others refer to age 50 or $60 \mathrm{y}$. Nevertheless, the recommendation to vaccinate elderly people is a key component of almost all influenza immunization strategies. The distribution in age recommendations among 31 EU/EEA countries plus Iceland, Liechtenstein and Norway, varies as follows: $3.2 \%$ ( 1 country) recommends that vaccination commence at $50 \mathrm{y}$ of age, $19.4 \%$ (6 countries) at $60 \mathrm{y}$ and older, and $77.4 \%$ (24 countries) at $65 \mathrm{y}$ and older. ${ }^{70}$ Similar recommendations have been set by Russia (age 60), and Australia (age 65). ${ }^{71,72}$ In the US and Canada, a markedly different approach is used-vaccination is recommended for all persons age 6 months and older. When the vaccine supply is limited, public health officials recommend a triaging of efforts to focus on the high risk groups, 
Table 2. Influenza vaccine recommendations for the elderly in Europe and selected countries.

\begin{tabular}{|c|c|c|}
\hline Country & $\begin{array}{l}\text { Recommendation for } \\
\text { elderly }\end{array}$ & $\begin{array}{l}\text { Target age } \\
\text { group }\end{array}$ \\
\hline Poland & YES & $\geq 55$ years \\
\hline Germany, Greece, Hungry, Iceland, Netherlands, Slovakia & YES & $\geq 60$ years \\
\hline $\begin{array}{l}\text { Austria, Belgium, Bulgaria, Croatia, Cyprus, Czech Republic, Denmark, Estonia, Finland, France, Ireland, Italy, Latvia, } \\
\text { Liechtenstein, Lithuania, Luxembourg, Malta, Norway, Portugal, Romania, Slovenia, Spain, Sweden, United Kingdom¹) }\end{array}$ & YES & $\geq 65$ years \\
\hline Russia $^{2)}$ & YES & $\geq 60$ years \\
\hline Australia & YES & $\geq 65$ years \\
\hline United States ${ }^{4)}$ & YES & All adults \\
\hline (anada ${ }^{5)}$ & YES & All adults \\
\hline |srael $^{6)}$ & YES & $\geq 65 y$ \\
\hline
\end{tabular}

1) ECDC Vaccine schedule: influenza

2) Ministry of Public Health of Russia

3) Australian Government, Department of Health, Australian Technical Advisory Group on Immunization (ATAGI)

4) CDC Atlanta, Advisory Committee for Immunization Practices (ACIP)

5) Public Health Agency of Canada, National Advisory Committee on Immunization ( $\mathrm{NACl})$

6) Ministry of Health, Israel

including all persons aged $50 \mathrm{y}$ and older in US plus pregnant women and those with underlying chronic conditions. Vaccination is generally free of charge in developed countries.

Despite the fact that recommendations have been developed and implemented in most developed countries for decades, influenza cannot be eradicated for several reasons. First, most avian species and swine are natural hosts to influenza A viruses. They support the circulation and reassortment of influenza A, making it impossible to interrupt this cycle. Additionally, the influenza virus is particularly adept at changing its antigenicity, requiring annual vaccine updates. Complicating the vaccination effort is the annual uncertainty of vaccine match to virus, and thus perceived and actual effectiveness, making planning supply and distribution difficult. ${ }^{73}$ Finally, some countries have very low vaccination coverage (approximately 30\%) among high risk adults younger than $65 \mathrm{y}$ of age. ${ }^{72}$

The rate of influenza vaccination in the elderly population is markedly different in various countries. Only a few countries have achieved the WHO-recommended influenza vaccine coverage goals of $50 \%$ by 2006 for adults aged $60 \mathrm{y}$ and older, and $75 \%$ by $2010 .^{74,75}$ In some countries, the vaccination rate among those age $65 \mathrm{y}$ or more is quite high, such as in South Korea where $75.8 \%$ have been vaccinated, Australia (70.9\%), US (71.5\%), UK (70.8\%), New Zealand (68\%), Canada (60\%), and Ireland (59\%). ${ }^{76,77,78,79}$ Vaccination coverage is quite variable, and increases in coverage are not guaranteed. In Italy, a dramatic decrease was noted, from $70 \%$ in $2005-2006$ to $48.6 \%$ in $2014-2015,{ }^{80}$ and in Canada coverage decreased $9 \%$ between 2006 and 2014 among those 65 and older, and 11\% during the same period for the very elderly age $85 \mathrm{y}$ and older. ${ }^{81}$

Disparities in vaccination coverage by region, and even within countries and communities, is influenced by a variety of factors. The media plays an increasingly important role in shaping public perspective. As with all vaccines, active discussion regarding benefits and potential risks extends to influenza vaccination generally, and specifically regarding the elderly. We turn now to a meta-analysis published recently and its impact on the clinical conversation as well as public response.

\section{Cochrane Review and its limitations}

While most doctors in the US and globally agree with the CDC recommendation to vaccinate people at the population level, a Cochrane review casts doubt as to whether the vaccine has any efficacy against influenza. ${ }^{82}$

Opponents of vaccination against influenza have recently used arguments based on a Cochrane's meta-analysis of immunization trials which concluded that flu vaccines offer no benefit. ${ }^{83}$ Presentation of these results in the media serve to mobilize the anti-vaccine constituency and invigorate resolve to refuse other vaccinations. The European Scientific Working Group on Influenza (ESWI) refutes the Cochrane findings, stating that any doubt regarding the benefits of influenza vaccination is dangerous from both a scientific and ethical point of view. Specifically, the ESWI points out that the Cochrane Review failed to distinguish between seasons with high, mild or no circulation of an influenza virus, a factor which would dramatically influence any final effectiveness estimate. ${ }^{84}$

The current media discussion is based on a dramatic misinterpretation of 2 scientific notions: efficacy and effectiveness of influenza vaccines. Effectiveness studies measure the level of protection offered by the influenza vaccine against influenzalike-illnesses. However, it is common scientific knowledge that influenza vaccines offer no protection against viruses other than the circulating influenza viruses.

Efficacy is more specific to influenza virus, however efficacy studies require thorough laboratory investigation. When the data are risk-stratified, a rigorous analysis yields substantial evidence in favor of the influenza vaccine to reduce the risk of influenza infection and influenza-related disease and death in the elderly. ${ }^{84,85}$

\section{Safety of influenza vaccines in elderly}

Issue of influenza vaccine safety is very sensitive since flu vaccines have the reputation of being reactogenic. However this may be mostly explained by differences in adverse events reporting and especially there may be bias in non-placebo-controlled trials. 
In reality influenza vaccines are generally well tolerated and safe in elderly. Serious and clinically important adverse events after vaccination are rare in elderly. The majority of adverse events resolved within $3 \mathrm{~d}$. But less information about the proportion of adverse events after influenza vaccination is available from the clinical trials for elderly compare with children or younger adults. The most common local reactions are pain, erythema, swelling and induration. In the large clinical trial in the Netherlands, $23 \%$ of patients aged $60 \mathrm{y}$ and older, reported one or more adverse reaction compared with $14 \%$ given placebo. The frequency of local reactions was $17.5 \%$ (7.3\% in placebo group) and no difference in systemic reactions $(11.4 \% \mathrm{v}$ 9.4\%) ${ }^{86}$ Results indicate lower proportion of local reactions in elderly than in children or young adult. Local reactions were reported in from $20-57 \%$ of the recipients aged $6-33$ y. ${ }^{87}$ Clinical trials reported swelling up to $7.3 \%$ of vaccinated elderly aged $60 \mathrm{y}$ and older. Local reactions are reported more frequently among the high-dose recipients (36\% reported pain) than among standard-dose flu vaccine recipients ( $24 \%$ reported pain) in $65 \mathrm{y}$ of age or older in US. Also swelling and erythema are more frequent following high-dose vaccine compared with the standard-dose vaccine. Administration route can influence occurrence of adverse events. The incidence of injection-site reaction was higher following the intradermal than intramuscular vaccination. The proportion of systemic reaction among elderly is a small, without the evidence of significant elevated risk compared with placebo recipients. The most common systemic reaction reported in elderly (65 y or older) within $7 \mathrm{~d}$ after influenza vaccination are malaise (7.2\%), fever (5.7\%), cough $(6.6 \%)$, coryza $(13.2 \%)$ or nausea $(4.5 \%)$. There are also no signs of safety risk for concomitant vaccination with other adult formulation of vaccines (zoster, pneumococcal or tetanus-diphteria-acellular pertussis vaccines) compared with separate administration in elderly. ${ }^{88}$

\section{Practical recommendation: When to immunize}

The optimal timing for influenza vaccination is before the influenza season, and more precisely, before the onset of influenza activity in the population. This time cannot be predicted exactly because the timing and duration of influenza season varies each year. In addition, some countries experience biannual outbreaks. The matter is complicated by the immune response, which also varies by age. Protective antibody levels decline over time, and this degradation of response is more pronounced in the elderly, particularly against influenza A/H3N2. Thus, questions regarding the ideal timing for vaccination have arisen with an emphasis on optimal timing of vaccination for the elderly.

Some studies suggest that a very proactive vaccination stance before flu season runs the risk of insufficient antibodies levels later when the influenza outbreak commences. ${ }^{89}$ A study in Spain during the 2011-2012 season demonstrated this risk; the influenza odds ratio (OR) was 20.81 for persons $\geq 65 \mathrm{y}$ vaccinated $>120 \mathrm{~d}$ before diagnosis versus those vaccinated $<100 \mathrm{~d}$ before diagnosis. ${ }^{90}$ Similarly, a case-control analysis from the 2007-2008 season described a significant increase in the OR for contracting influenza every $14 \mathrm{~d}$ after vaccination among adults aged
$75 \mathrm{y}$ (1.3 for each $14 \mathrm{~d}$ interval). ${ }^{91}$ Delaying vaccination in the elderly until later in the season may confer a greater likelihood of sufficient immunity, but this strategy may result in missed opportunities to administer vaccine concurrent with regularly scheduled clinic visits. Usually, the recommendation is to vaccinate against influenza by the end of October, however, vaccination in December or later could be beneficial, especially for elderly. ${ }^{69}$

\section{Future vaccine development}

A multi-pronged strategy to optimize vaccine immunogenecity includes using adjuvants, modifying the route of administration, dosage, and composition of the vaccine. The immunogenicity of adjuvants, such as alum, have demonstrated mixed results. ${ }^{92,93,94,95}$ A novel strategy to use TLR agonists increases the co-expression of costimulatory molecules (i.e. CD40, CD86 and MHCII) in aged mouse and human cell models; this strategy also appears to restore B cell expansion..$^{96}$ An oil-in-water emulsion, such as MF59 or AS03, has also shown increased immunogenicity, cross-reactivity to other influenza strains, and a $25-50 \%$ reduction in hospitalization. ${ }^{49}$

The intranasal and intramuscular injection sites seem to recruit different $\mathrm{T}$ lymphocytes, ${ }^{97}$ but intranasal live-attenuated vaccines have not been effective in the elderly. ${ }^{98}$ The potential advantages of intradermal administration for vaccines are currently being investigated and side-by-side comparisons are promising. ${ }^{99,100,101}$ A meta-analysis of 13 trials concluded that among the elderly, a higher intradermal dose conferred an immunogenic advantage when compared with intramuscular administration. ${ }^{102}$

Boosting the vaccine dose 4-fold may confer a concomitant increase in antigenic presentation. ${ }^{103,104,105,106}$ However, as noted previously, perhaps a better hallmark of immunogenicity and durability of protection in the elderly is the $\mathrm{T}$ lymphocyte response measured by ex vivo cytokine and granzyme B production, not antibody titers. ${ }^{107}$ Further, the immune response to actual infection differs from that prompted by immunization. Inactivated vaccines induce a decent neutralizing antibody response, but $\mathrm{T}$ cells are generally only mobilized by natural infection. For example, fewer than $50 \%$ of older individuals may demonstrate a CTL response following immunization with the live attenuated vaccine. ${ }^{108}$ Thus, an entirely novel vaccine model which engages both $\mathrm{CD} 4+$ and CD8+ CTL may be required to induce a robust immune response in the elderly.

To this end, various approaches to vaccine construction are currently under development to exploit the inherent characteristics of the influenza virus. Because the influenza nucleoprotein (NP) contains immunodominant epitopes for both CD4 and CD8 T cells, ${ }^{109}$ a vaccine which incorporates NP may elicit good $\mathrm{T}$ cell immunity, and importantly, confer protection against multiple strains. One such prototype vaccine with NP and matrix 1 influenza proteins has been developed using modified Vaccinia Virus Ankara (MVA). ${ }^{110}$ Initial indications suggest this vaccine is safe and promotes a $\mathrm{T}$ cell response in people 50-85 y old comparable to a younger population ${ }^{111}$; however, it is uncertain whether an antibody response is produced. 


\section{Conclusion}

Despite the relatively short duration of illness and short period of seasonal influenza each year, the medical and economic burden is substantial because the pathogen is highly infectious, and certain risk groups suffer severe sequelae requiring prompt intervention. Although immunization remains the most important preventive measure, scientific papers which suffer from methodological problems or a lack of balance have prompted questions about the value of immunization. There is an exigent need to properly position the role of influenza vaccination with respect to the target population, goals of vaccination, and strategies to optimize effectiveness.

These challenges have triggered a vigorous response which promises to advance vaccine technology in general. Given the complex cellular interactions affected by aging, optimal vaccine development must engage in a similarly complex matrix of strategies. Older adults are, for the first time in history, the most rapidly expanding age group. ${ }^{112}$ To reduce influenza morbidity and mortality in this important yet vulnerable group, the ideal vaccine should induce good humoral and cellular responses. For instance, novel target antigens may reduce the need for a unique annual vaccine, increasing the duration of effectiveness from season to season. Advances in this regard would obviously be of benefit to younger patients as well, making this line of research particularly productive.

\section{Disclosure of potential conflicts of interest}

Dr. Shaw served on Pfizer Advisory Board.

Dr. Prymula is member of ESWI.

All other authors have no potential conflicts of interest.

\section{Acknowledgment}

This article benefited from the thoughtful editorial contributions of Allison Krug, MPH.

\section{Funding}

This article was supported by research project "Excellency of University Hradec Kralove."

\section{ORCID}

Jan Smetana (iD http://orcid.org/0000-0002-3770-1754

Roman Chlibek (iD) http://orcid.org/0000-0002-7387-3844

Jana Shaw (iD http://orcid.org/0000-0003-0955-3392

Roman Prymula (iD http://orcid.org/0000-0003-1567-2259

\section{References}

[1] Udalkis L. Influenza. Available from: https://www.microbiologysoci ety.org/uploads/assets/uploaded/4e60089d-47b7-41af-95c3e71a2133 d40f.pdf (accessed July 2017)

[2] Lamb RA, Krug RM. Orthomyxoviridae: the viruses and their replication. In: Knipe DM, Howley PM, editors. eds. Fields Virology Vol 1, 4th ed. Philadelphia, PA: Lippincott Williams \& Wilkins 2001:1487-1531.

[3] Cox NJ, Subbarao K. Influenza. Lancet 1999; 354:1277-82; PMID:10520648; https://doi.org/10.1016/S0140-6736(99)01241-6.
[4] Hayward AC, Fragaszy EB, Bermingham A, Wang L, Copas A, Edmunds WJ, Ferguson N, Goonetilleke N, Harvey G, Kovar J, et al. Comparative community burden and severity of seasonal and pandemic influenza: results of the Flu Watch cohort study. Lancet Respir Med 2014; 2(6):445-54; PMID:24717637; https://doi.org/ 10.1016/S2213-2600(14)70034-7.

[5] Rasmussen SA, Jamieson DJ, Uyeki TM. Effects of influenza on pregnant women and infants. Am J Obstet Gynecol 2012; 207(3 Suppl): S3-8; PMID:22920056; https://doi.org/10.1016/j.ajog.2012.06.068.

[6] World Health Organization. Influenza. Available from: http://www. who.int/mediacentre/factsheets/2003/fs211/en (accessed July 2017)

[7] ECDC. Flu season starts. Available from: https://ecdc.europa.eu/en/ news-events/flu-season-starts (accessed July 2017)

[8] Wong CM, Chan KP, Hedley AJ, Peiris JS. Influenza-associated mortality in Hong Kong. Clin Infect Dis 2004; 39:1611-7; PMID:15578360; https://doi.org/10.1086/425315.

[9] Rothberg MB, Haessler SD, Brown RB. Complications of viral influenza. Am J Med 2008; 121:258-64; PMID:18374680; https://doi.org/ 10.1016/j.amjmed.2007.10.040.

[10] Thompson WW, Comanor L, Shay DK. Epidemiology of seasonal influenza: use of surveillance data and statistical models to estimate the burden of disease. J Infect Dis 2006; 194(Suppl 2):S82-91; PMID:17163394; https://doi.org/10.1086/507558.

[11] Fleming DM, Taylor RJ, Haguinet F, Schuck-Paim C, Logie J, Webb DJ, Lustig RL, Matias G. Influenza-attributable burden in United Kingdom. Epidemiol Infect 2016; 144:537-47; PMID:26168005; https://doi.org/10.1017/S0950268815001119.

[12] Falsey AR, Hennessey PA, Formica MA, Cox C, Walsh EE. Respiratory syncytial virus infection in elderly and high-risk adults. N Engl J Med 2005; 352:1749-59; PMID:15858184; https://doi.org/10.1056/ NEJMoa043951.

[13] Thompson WW, Shay DK, Weintraub E, Brammer L, Cox N, Anderson LJ, Fukuda K. Mortality associated with influenza and respiratory syncytial virus in the United States. JAMA 2003; 289:179-86; PMID:12517228; https://doi.org/10.1001/ jama.289.2.179.

[14] Gasparini R, Amicizia D, Lai P, Panatto D. Clinical and socioeconomic impact of seasonal and pandemic influenza in adults and the elderly, Human Vaccines \& Immunotherapeutics 2012; $8(1): 21-28$.

[15] Centers for Disease Control and Prevention (CDC). Estimates of deaths associated with seasonal influenza - United States, 19762007. MMWR Morb Mortal Wkly Rep 2010; 59(33):1057-62; PMID:20798667.

[16] Reed C, Chaves SS, Daily Kirley P, Emerson R, Aragon D, Hancock EB, Butler L, Baumbach J, Hollick G, Bennett NM, et al. Estimating influenza disease burden from population-based surveillance data in the United States. PLoS One 2015; 10(3):e0118369; PMID:25738736; https://doi.org/10.1371/journal.pone.0118369.

[17] Linhart Y, Shohat T, Bromberg M, Mendelson E, Dictiar R, Green MS. Excess mortality from seasonal influenza is negligible below the age of 50 in Israel: implications for vaccine policy. Infection 2011; 39(5):399-404; PMID:21887527; https://doi.org/10.1007/ s15010-011-0153-1.

[18] Molinari NA, Ortega-Sanchez IR, Messonnier ML, Thompson WW, Wortley PM, Weintraub E, Bridges CB. The annual impact of seasonal influenza in the US: measuring disease burden and costs. Vaccine 2007; 25(27):5086-96; PMID:17544181; https://doi.org/ 10.1016/j.vaccine.2007.03.046.

[19] Gasparini R, Amicizia D, Lai PL, Panatto D. Clinical and socioeconomic impact of seasonal and pandemic influenza in adults and the elderly. Hum Vaccin Immunother 2012; 8(1):21-8; PMID:22252007; https://doi.org/10.4161/hv.8.1.17622.

[20] Lai PL, Panatto D, Ansaldi F, Canepa P, Amicizia D, Patria AG, Gasparini R. Burden of the 1999-2008 seasonal influenza epidemics in Italy - Comparison with the H1N1v (A/California/07/09) pandemic. Hum Vaccin 2011; 7:217-25; PMID:21922688; https://doi org/10.4161/hv.7.0.14607.

[21] Xue Y, Kristiansen IS, de Blasio BF. Modeling the cost of influenza: the impact of missing costs of unreported complications and sick 
leave. BMC Public Health 2010; 10:724; PMID:21106057; https:// doi.org/10.1186/1471-2458-10-724.

[22] Aballéa S, Chancellor J, Martin M, Wutzler P, Carrat F, Gasparini $\mathrm{R}$, Toniolo-Neto J, Drummond M, Weinstein M. The cost-effectiveness of influenza vaccination for people aged 50 to 64 years: an international model. Value Health 2007; 10(2):98-116; PMID:17391419; https://doi.org/10.1111/j.1524-4733.2006.00157.x.

[23] Baguelin M, Jit M, Miller E, Edmunds WJ. Health and economic impact of the seasonal influenza vaccination programme in England. Vaccine 2012; 30(23):3459-62; PMID:22446636; https://doi. org/10.1016/j.vaccine.2012.03.019.

[24] Maciosek MV, Solberg LI, Coffield AB, Edwards NM, Goodman MJ. Influenza vaccination health impact and cost effectiveness among adults aged 50 to 64 and 65 and older. Am J Prev Med 2006; 31(1):72-9; PMID:16777545; https://doi.org/10.1016/j. amepre.2006.03.008.

[25] Newall AT, Dehollain JP. The cost-effectiveness of influenza vaccination in elderly Australians: an exploratory analysis of the vaccine efficacy required. Vaccine 2014; 32(12):1323-5; PMID:24486359; https://doi.org/10.1016/j.vaccine.2014.01.017.

[26] Ryan J, Zoellner Y, Gradl B, Palache B, Medema J. Establishing the health and economic impact of influenza vaccination within the European Union 25 countries. Vaccine 2006; 24(4748):6812-22.

[27] de Waure C, Veneziano MA, Cadeddu C, Capizzi S, Specchia ML, Capri S, Ricciardi W. Economic value of influenza vaccination. Hum Vaccin Immunother 2012; 8(1):119-29; PMID:22251999; https://doi.org/10.4161/hv.8.1.18420.

[28] Centers for Disease Control and Prevention. Vaccine effectiveness How well does the flu vaccine work? Available from: https://www. cdc.gov/flu/about/qa/vaccineeffect.htm (accessed July 2017)

[29] Measures of Public Health Impact. Available from: https://www.cdc. gov/ophss/csels/dsepd/ss1978/lesson3/section6.html [accessed July 2017].

[30] Murphy K, Weaver C. Janeway's Immunobiology. New York; Garland Science; 2016, 9th edition 904p.

[31] Goodwin K, Viboud C, Simonsen L. Antibody response to influenza vaccination in the elderly: a quantitative review. Vaccine 2006; 24(8):1159-69; PMID:16213065; https://doi.org/ 10.1016/j.vaccine.2005.08.105.

[32] Moro-García MA, Alonso-Arias R, López-Larrea C. Molecular Mechanisms Involved in the Aging of the T-cell Immune Response. Current Genomics 2012; 13(8):589-602; PMID:23730199; https:// doi.org/10.2174/138920212803759749.

[33] Gomez CR, Boehmer ED, Kovacs EJ. The aging innate immune system. Curr Opin Immunol 2005; 17:457-62; PMID:16084711; https://doi.org/10.1016/j.coi.2005.07.013.

[34] Vasselon T, Detmers PA. Toll Receptors: a central element in innate immune responses Infect Immun 2002; 70(3):1033-41; PMID:11854180; https://doi.org/10.1128/IAI.70.3.1033-1041.2002.

[35] Renshaw M, Rockwell J, Engleman C, Gewirtz A, Katz J, Sambhara S. Cutting edge: impaired Toll-like receptor expression and function in aging. J Immunol 2002; 169:4697-701; PMID:12391175; https:// doi.org/10.4049/jimmunol.169.9.4697.

[36] Grewe M. Chronological ageing and photoageing of dendritic cells. Clin Exp Dermatol 2001; 26:608-12; PMID:11696065; https://doi. org/10.1046/j.1365-2230.2001.00898.x.

[37] van Duin D, Shaw AC. Toll-like receptors in older adults. J Am Geriatr Soc 2007; 55:1438-44; PMID:17767688; https://doi.org/ 10.1111/j.1532-5415.2007.01300.x.

[38] Effros RB, Walford RL. T-Cell Cultures and the Hayflick Limit. Human Immunology 1984; 9(1):49-65; PMID:6607244; https://doi. org/10.1016/0198-8859(84)90006-5.

[39] Messaoudi I, Lemaoult J, Guevara-Patino JA, Metzner BM, Nikolich-Zugich J. Age-related CD8 T cell clonal expansions constrict CD8 $\mathrm{T}$ cell repertoire and have the potential to impair immune defense. J Exp Med 2004; 200(10):1347-58.

[40] Yager EJ, Ahmed M, Lanzer K, Randall TD, Woodland DL, Blackman MA. Age-associated decline in T cell repertoire diversity leads to holes in the repertoire and impaired immunity to influenza virus. J Exp Med 2008; 205(3):711-23; PMID: 18332179; https://doi. org/10.1084/jem.20040437.

[41] Murasko DM, Jiang J. Response of aged mice to primary virus infections. Immunol Rev 2005; 205:285-96; PMID:15882361; https://doi org/10.1111/j.0105-2896.2005.00273.x.

[42] Brien JD, Uhrlaub JL, Hirsch A, Wiley CA, Nikolich-Zugich J. Key role of $\mathrm{T}$ cell defects in age-related vulnerability to West Nile virus. J Exp Med 2009; 206(12):2735-45; PMID:19901080; https://doi.org/ 10.1084/jem.20090222.

[43] Cicin-Sain L, Smyk-Pearson S, Currier N, Byrd L, Koudelka C, Robinson T, Swarbrick G, Tackitt S, Legasse A, Fischer M, et al. Loss of naive $\mathrm{T}$ cells and repertoire constriction predict poor response to vaccination in old primates. J Immunol 2010; 184(12):6739-45; PMID:20483749; https://doi.org/10.4049/jimmunol.0904193.

[44] Goodwin K, Viboud C, Simonsen L. Antibody response to influenza vaccination in the elderly: a quantitative review. Vaccine 2006; 24:1159-69; PMID:16213065; https://doi.org/10.1016/ j.vaccine.2005.08.105.

[45] Weinberger B, Dietmar Herndler-Brandstetter D, Schwanninger A, Weiskopf D, Grubeck-Loebenstein B. Biology of immune responses to vaccines in elderly persons. Clin Infect Dis 2008; 46(7):1078-84; PMID:18444828; https://doi.org/10.1086/529197.

[46] Hsu HC, Scott DK, Mountz JD. Impaired apoptosis and immune senescence - cause or effect? Immunol Rev 2005; 205:130-46; PMID:15882350; https://doi.org/10.1111/j.0105-2896.2005.00270.x.

[47] Haynes L, Linton PJ, Eaton SM, Tonkonogy SL, Swain SL. Interleukin 2, but not other common gamma chain-binding cytokines, can reverse the defect in generation of $\mathrm{CD} 4$ effector $\mathrm{T}$ cells from naive $\mathrm{T}$ cells of aged mice. J Exp Med 1999; 190(7):1013-24; PMID:10510091; https://doi.org/10.1084/jem.190.7.1013.

[48] Eaton ME, Burns EM, Kusser K, Randall TD, Haynes L. Age-related defects in CD4 T cell cognate helper function lead to reductions in humoral responses. J Exp Med 2004; 200(12):1613-22; PMID:15611289; https://doi.org/10.1084/jem.20041395.

[49] McElhaney JE, Beran J, Devaster JM, Esen M, Launay O, LerouxRoels G, Ruiz-Palacios GM, van Essen GA, Caplanusi A, Claeys C et al. AS03-adjuvanted versus non-adjuvanted inactivated trivalent influenza vaccine against seasonal influenza in elderly people: a phase 3 randomised trial. Lancet Infect Dis 2013; 13(6):485-96; PMID:23518156; https://doi.org/10.1016/S1473-3099(13)70046-X.

[50] Stokes J, Chenoweth AD, Waltz AD, Gladen RG, Shaw D. Results of immunization by means of active virus of human influenza. J Clin Invest 1937; 16:237-43; PMID:16694474; https://doi.org/10.1172/ JCI100853.

[51] Commission on Influenza: A clinical evaluation of vaccination against influenza. JAMA 1944; 124:982-5; https://doi.org/10.1001/ jama.1944.62850140004008.

[52] Davenport FM. Current knowledge of influenza vaccine. JAMA 1962; 182:11-3; PMID:13883724; https://doi.org/10.1001/ jama.1962.03050400013003.

[53] ECDC. Influenza vaccination. Available from: http://ecdc.europa. eu/en/healthtopics/seasonal_influenza/vaccines/Pages/influenza_ vaccination.aspx (accessed July 2017)

[54] Grohskopf LA, Sokolow LZ, Olsen SJ, Bresee JS, Broder KR, Karron RA. Prevention and control of influenza with vaccines: recommendations of the advisory committee on immunization practices, United States, 2015-16 influenza season. Morb Mortal Wkly Rep 2015; 64:818-25; https://doi.org/10.15585/mmwr.mm6430a3.

[55] WHO. Meeting of the strategic advisory group of experts on immunization, April 2012 - conclusions and recommendations. Morbid Mortal Wkly Rep 2012; 87(21):201-16.

[56] MacIntyre CR, Heywood AE, Kovoor P, Ridda I, Seale H, Tan T, Gao Z, Katelaris AL, Siu HW, Lo V, et al. Ischaemic heart disease, influenza and influenza vaccination: a prospective case control study. Heart 2013; 99:1843-8; PMID:23966030; https://doi.org/ 10.1136/heartjnl-2013-304320.

[57] MacIntyre CR, Mahimbo A, Moa AM, Barnes M. Influenza vaccine as a coronary intervention for prevention of myocardial infarction Heart 2016; 102(24):1953-6; PMID:27686519; https://doi.org/ 10.1136/heartjnl-2016-309983. 
[58] Lambert ND, Ovsyannikova IG, Pankratz VS, Jacobson RM, Poland GA. Understanding the immune response to seasonal influenza vaccination in older adults: A systems biology approach. Expert Rev Vaccines 2012; 11(8):985-994; https://doi.org/10.1586/erv.12.61

[59] Castilla J, Martinez-Baz I, Martinez-Artola V, Reina G, Pozo F, Garcia Cenoz M, Guevara M, Moran J, Irisarri F, Arriazu M, et al. Decline in influenza vaccine effectiveness with time after vaccination, Navarre, Spain, season 2011/12. Euro Surveill 2013; 18(5): pii=20388. Available from: http://www.eurosurveillance.org/View Article.aspx?ArticleId $=20388$

[60] Pebody RG, Andrews N, McMenamin J, Durnall H, Ellis J, Thompson CI, Robertson C, Cottrell S, Smyth B, Zambon M, et al. Vaccine effectiveness of 2011/12 trivalent seasonal influenza vaccine in preventing laboratory-confirmed influenza in primary care in the United Kingdom: Evidence of waning intra-seasonal protection. Euro Surveill 2013; 18(5):pii=20389. Available from: http://www. eurosurveillance.org/ViewArticle.aspx?ArticleId=20389

[61] Young B, Xiahong Z, Cook AR, Parry CM, Smith AW, I-Cheng MC. Do antibody responses to the influenza vaccine persist yearround in the elderly? A systematic review and meta-analysis. Vaccine 2017; 35:212-221; PMID:27939013; https://doi.org/10.1016/j. vaccine.2016.11.013.

[62] Manzoli L, Ioannidis JP, Flacco ME, De Vito C, Villari P. Effectiveness and harms of seasonal and pandemic influenza vaccines in children, adults and elderly: a critical review and re-analysis of 15 metaanalyses. Hum Vaccin Immunother 2012; 8:851-62; PMID:22777099; https://doi.org/10.4161/hv.19917.

[63] Simonsen L, Taylor RJ, Viboud C, Miller MA, Jackson LA. Mortality benefits of influenza vaccination in elderly people: an ongoing controversy. Lancet Infect Dis 2007; 7:658-66; PMID:17897608; https://doi.org/10.1016/S1473-3099(07)70236-0.

[64] Jackson LA, Jackson ML, Nelson JC, Neuzil KM, Weiss NS. Evidence of bias in estimates of influenza vaccine effectiveness in seniors. Int J Epidemiol 2006; 35:337-44; PMID:16368725; https:// doi.org/10.1093/ije/dyi274.

[65] European Centre for Disease and Control (ECDC), Angus N, Tsolova S. In: ECDC, ed. Priority risk groups for influenza vaccination. 2008. Available from: https://ecdc.europa.eu/sites/portal/files/ media/en/publications/Publications/0808_GUI_Priority_Risk_Groups_ for_Influenza_Vaccination.pdf (accessed July 2017)

[66] Fleming DM, Elliot AJ. Estimating the risk population in relation to influenzavaccination policy. Vaccine 2006; 24(May (20):4378-85; PMID:16574281; https://doi.org/10.1016/j.vaccine.2006.02.053.

[67] Vaccines against influenza WHO position paper - November 2012. Wkly Epidemiol Rec 2012; 87:461-76; PMID:23210147.

[68] Mereckiene J, Cotter S, Nicoll A, Lopalco P, Noori T, Weber J, D’Ancona F, Levy-Bruhl D, Dematte L, Giambi C, et al. VENICE Project Gatekeepers Group. Seasonal influenza immunisation in Europe. Overview of recommendations and vaccination coverage for three seasons: pre-pandemic (2008/09), pandemic (2009/10) and post-pandemic (2010/11). Euro Surveill 2014; 19:20780; PMID:24786262; https://doi.org/10.2807/1560-7917. ES2014.19.16.20780.

[69] CDC. Prevention and Control of Seasonal Influenza with Vaccines Recommendations of the Advisory Committee on Immunization Practices - United States, 2016-17 Influenza Season. Morbid Mortal Weekly Rep 2016; 65(5):1-52.

[70] ECDC. Vaccine schedule. Recommended immunisations for influenza. Available from: http://vaccine-schedule.ecdc.europa.eu/Pages/ Scheduler.aspx (accessed January 2017)

[71] Ministry of Healthcare of the Russian Federation. Influenza vaccine. Available from: http://www.influenza.spb.ru/en/science_and_soci ety/influenza_vaccines/ (accessed January 2017)

[72] Australian Institute of Health and Welfare 2011. 2009 Adult Vaccination Survey: Summary results. Cat. no. PHE 135. Canberra: AIHW. Available from: http://www.aihw.gov.au/WorkArea/Down loadAsset.aspx?id=10737418286 (accessed July 2017)

[73] Fiore AE, Bridges CB, Katz JM, Cox NJ. Inactivated influenza vaccines. In: Plotkin SA, Orenstein WA, Offit PA, eds. Vaccines, 6th edition. Philadelphia: Elsevier Saunders; 2013; p. 257-293
[74] Thomas-Crusells J, McElhaney JE, Aguado MT. Report of the ad-hoc consultation on aging and immunization for a future WHO research agenda on life-course immunization. Vaccine 2012; 30:6007-12; PMID:22835737; https://doi.org/10.1016/j. vaccine.2012.07.025.

[75] Palache A, Oriol-Mathieu V, Fino M, Xydia-Charmanta M. Seasonal influenza vaccine dose distribution in 195 countries (20042013): little progress in estimated global vaccination coverage. Vaccine 2015; 33:5598-605; PMID:26368399; https://doi.org/10.1016/j. vaccine.2015.08.082.

[76] Karki S, Dyda A, Newall A, Heywood A, MacIntyre CR, McIntyre P, Banks E, Liu B. Comparison of influenza vaccination coverage between immigrant and Australian-born adults. Vaccine 2016; 34:6388-95; PMID:27742215; https://doi.org/ 10.1016/j.vaccine.2016.10.012.

[77] Kwon DS, Kim K, Park SM. Factors associated with influenza vaccination coverage among the elderly in South Korea: the Fourth Korean National Health and Nutrition Examination Survey. MBJ Open 2016; 6:e012618.

[78] CDC. Surveillance of Vaccination Coverage Among Adult Population - United States, 2014. Morbid Mortal Weekly Rep 2016; 65 (1):1-38.

[79] Giese C, Mereckiene J, Danis K, O'Donnell J, O'Flanagan D, Cotter S. Low vaccination coverage for seasonal influenza and pneumococcaldisease among adults at-risk and health care workers in Ireland, 2013:The key role of GPs in recommending vaccination. Vaccine 2016; 34:3657-62; PMID:27255466; https:// doi.org/10.1016/j.vaccine.2016.05.028.

[80] Gasparini R, Amicizia D, Lai PL, Panatto D. Influenza vaccination: from epidemiological aspects and advances in research to dissent and vaccination policies. J Prev Med Hyg 2016; 57:E1-4; PMID:27346933.

[81] Buchan SA, Kwong JC. Trends in influenza vaccine coverage and vaccine hesitancy in Canada, 2006/07 to 2013/14: results from cross-sectional survey data. CMAJ Open 2016; 4(3):E455-62; PMID:27975047; https://doi.org/10.9778/cmajo.20160050.

[82] Jefferson T, Di Pietrantonj C, Rivetti A, Bawazeer GA, Al-Ansary LA, Ferroni E. Vaccines for preventing influenza in healthy adults. Cochrane Database Syst Rev 2010; (7):CD001269. PMID:20614424

[83] Jefferson T, Di Pietrantonj C, Al-Ansary LA, Ferroni E, Thorning S, Thomas RE. Vaccines for preventing influenza in the elderly. Cochrane Database Syst Rev 2010; (2); PMID:20166072; https://doi. org/10.1002/14651858.CD004876.pub3

[84] Beyer WE, McElhaney J, Smith DJ, Monto AS, Nguyen-Van-Tam JS, Osterhaus AD. Cochrane re-arranged: support for policies to vaccinate elderly people against influenza. Vaccine 2013; 31(50):6030-3; PMID:24095882; https://doi.org/10.1016/j.vaccine.2013.09.063.

[85] Van-Tam J. Are influenza vaccines effective for the elderly? 4th ESWI Science Policy Flu Summit, Brussels, September 2015

[86] Govaert TM, Dinant GJ, Aretz K, Masurel N, Sprenger MJ, Knottnerus JA. Adverse reactions to influenza vaccine in elderly people: randomised double blind placebo controlled trial. BMJ 1993; 307(6910):988-90; PMID:8241913; https://doi.org/10.1136/ bmj.307.6910.988.

[87] Barry DW, Mayner RE, Hochstein HD, Dunlap RC, Rastogi SC, Hannah JE, Blackburn RJ, Sullivan JL, Gerety RJ. Comparative trial of influenza vaccines. II. Adverse reactions in children and adults. Am J Epidemiol 1976; 104(1):47-59; PMID:132867; https://doi.org/ 10.1093/oxfordjournals.aje.a112273.

[88] Rowhani-Rahbar A, Klein NP, Baxter R. Assessing the safety of influenza vaccination in specific populations children and the elderly. Expert Rev Vaccines 2012; 11(8):973-984.

[89] Song JY, Cheong HJ, Hwang IS, Choi WS, Jo YM, Park DW, Cho GJ, Hwang TG, Kim WJ. Long-term immunogenicity of influenza vaccine among the elderly: Risk factors for poor immune response and persistence. Vaccine 2010; 28:3929-35; PMID:23002978; https://doi.org/10.1586/erv.12.66.

[90] Castilla J, Martínez-Baz I, Martínez-Artola V, Reina G, Pozo F, García Cenoz M, Guevara M, Morán J, Irisarri F, Arriazu M, et al. Primary Health Care Sentinel Network; Network for 
Influenza Surveillance in Hospitals of Navarre. Decline in influenza vaccine effectiveness with time after vaccination, Navarre, Spain, season 2011/12. Euro Surveill 2013; 18:20388; PMID:23399423.

[91] Belongia EA, Sundaram ME, McClure DL, Meece JK, Ferdinands J, VanWormer JJ. Waning vaccine protection against influenza A (H3N2) illness in children and older adults during a single season. Vaccine 2015; 33:246-51; https://doi.org/ 10.1016/j.vaccine.2014.06.052.

[92] Harada Y, Ninomiya-Mori A, Takahashi Y, Shirakura M, Kishida $\mathrm{N}$, Kageyama $\mathrm{T}$, Tada $\mathrm{Y}$, Tashiro $\mathrm{M}$, Odagiri $\mathrm{T}$. Inactivated and adjuvanted whole-virion clade 2.3. $4 \mathrm{H} 5 \mathrm{~N} 1$ pre-pandemic influenza vaccine possesses broad protective efficacy against infection by heterologous clades of highly pathogenic $\mathrm{H} 5 \mathrm{~N} 1$ avian influenza virus in mice. Vaccine 2011; 29:8330-7; https://doi.org/10.1016/j. vaccine.2011.08.091.

[93] Ninomiya A, Imai $M$, Tashiro $M$, Odagiri T. Inactivated influenza H5N1 whole-virus vaccine with aluminum adjuvant induces homologous and heterologous protective immunities against lethal challenge with highly pathogenic $\mathrm{H} 5 \mathrm{~N} 1$ avian influenza viruses in a mouse model. Vaccine 2007; 25:3554-60; PMID:17293015; https:// doi.org/10.1016/j.vaccine.2007.01.083.

[94] Nolan TM, Richmond PC, Skeljo MV, Pearce G, Hartel G, Formica NT, Hoschler K, Bennet J, Ryan D, Papanaoum K, et al. Phase I and II randomised trials of the safety and immunogenicity of a prototype adjuvanted inactivated split-virus influenza A (H5N1) vaccine in healthy adults. Vaccine. 2008; 26:4160-7; PMID:18599164; https://doi.org/10.1016/j.vaccine.2008.05.077.

[95] Zhu FC, Wang H, Fang HH, Yang JG, Lin XJ, Liang XF, Zhang XF, Pan HX, Meng FY, Hu YM, et al. A novel influenza A (H1N1) vaccine in various age groups. N Engl J Med 2009; 361:2414-23; PMID:19846844; https://doi.org/10.1056/NEJMoa0908535.

[96] Maue AC, Eaton SM, Lanthier PA, Sweet KB, Blumerman SL, Haynes L. Proinflammatory adjuvants enhance the cognate helper activity of aged CD4 T cells. J Immunol 2009; 182:6129-35; PMID:19414765; https://doi.org/10.4049/jimmunol.0804226.

[97] Diebold SS. Determination of T-cell fate by dendritic cells. Immunol Cell Biol 2008; 86:389-97; PMID:18382438; https://doi.org/ 10.1038/icb.2008.26.

[98] Powers DC, Fries LF, Murphy BR, Thumar B, Clements ML. In elderly persons live attenuated influenza $A$ virus vaccines do not offer an advantage over inactivated virus vaccine in inducing serum or secretory antibodies or local immunologic memory. J Clin Microbiol 1991; 29:498-505; PMID:2037667

[99] Durando P, Iudici R, Alicino C, Alberti M, de Florentis D, Ansaldi F, Icardi G. Adjuvants and alternative routes of administration towards the development of the ideal influenza vaccine. Hum Vaccin 2011; 7(Suppl):29-40; PMID:21245655; https://doi.org/10.4161/ hv.7.0.14560.

[100] Ansaldi F, Orsi A, de FD, Parodi V, Rappazzo E, Coppelli M, Durando P, Icardi G. Head-to-head comparison of an intradermal and a virosome influenza vaccine in patients over the age of 60 : Evaluation of immunogenicity, cross-protection, safety and tolerability. Hum Vaccin Immunother. 2013; 9:591-8; PMID:23295262; https://doi.org/10.4161/hv.23240.

[101] Holland D, Booy R, De LF, Eizenberg P, McDonald J, Karrasch J, McKeirnan M, Salem H, Mills G, Reid J, et al. Intradermal influenza vaccine administered using a new microinjection system produces superior immunogenicity in elderly adults: a randomized controlled trial. J Infect Dis. 2008; 198:650-658; PMID:18652550; https://doi. org/10.1086/590434

[102] Marra F, Young F, Richardson K, Marra CA. A Meta-analysis of intradermal versus intramuscular influenza vaccines: Immunogenicity and Adverse Events. Influenza Other Respir Viruses 2013; 7(4):584-603.

[103] DiazGranados CA, Dunning AJ, Jordanov E, Landolfi V, Denis M, Talbot HK. High-dose trivalent influenza vaccine compared to standard dose vaccine in elderly adults: safety, immunogenicity and relative efficacy during the 2009-2010 season. Vaccine 2013; 31:861-6; PMID:23261045; https://doi.org/10.1111/irv.12000.

[104] Chen WH, Cross AS, Edelman R, Sztein MB, Blackwelder WC, Pasetti MF. Antibody and Th1- type cell-mediated immune responses in elderly and young adults immunized with the standard or a high dose influenza vaccine. Vaccine 2011; 29:2865-73; PMID:21352939; https://doi.org/10.1016/j.vaccine.2011.02.017.

[105] Falsey AR, Treanor JJ, Tornieporth N, Capellan J, Gorse GJ. Randomized, double-blind controlled phase 3 trial comparing the immunogenicity of high-dose and standard-dose influenza vaccine in adults 65 years of age and older. J Infect Dis 2009; 200:172-80; PMID:19508159; https://doi.org/10.1086/599790.

[106] Keitel WA, Atmar RL, Cate TR, Petersen NJ, Greenberg SB, Ruben F, Couch RB. Safety of high doses of influenza vaccine and effect on antibody responses in elderly persons. Arch Intern Med 2006; 166:1121-7; PMID:16717175; https://doi.org/10.1001/ archinte.166.10.1121.

[107] McElhaney JE, Xie D, Hager WD, Barry MB, Wang Y, Kleppinger A, Ewen C, Kane KP, Bleackley RC. T cell responses are better correlates of vaccine protection in the elderly. J Immunol 2006; 176(10):6333-9; PMID:16670345; https://doi. org/10.4049/jimmunol.176.10.6333.

[108] Gorse GJ, O’Connor TZ, Newman FK, Mandava MD, Mendelman PM, Wittes J, Peduzzi PN. Immunity to influenza in older adults with chronic obstructive pulmonary disease. J Infect Dis 2004; 190:11-9; PMID:15195238; https://doi.org/10.1086/421121.

[109] Doucet JD, Forget MA, Grange C, Rouxel RN, Arbour N, von MV, Lapointe R. Endogenously expressed matrix protein M1 and nucleoprotein of influenza $\mathrm{A}$ are efficiently presented by class I and class II major histocompatibility complexes. J Gen Virol 2011; 92:1162-71; PMID:21307226; https://doi.org/ 10.1099/vir.0.029777-0

[110] Berthoud TK, Hamill M, Lillie PJ, Hwenda L, Collins KA, Ewer KJ Milicic A, Poyntz HC, Lambe T, Fletcher HA, et al. Potent CD8+ T-cell immunogenicity in humans of a novel heterosubtypic influenza A vaccine, MVA-NP+M1. Clin Infect Dis. 2011; 52:1-7; PMID:21148512; https://doi.org/10.1093/cid/ciq015.

[111] Antrobus RD, Lillie PJ, Berthoud TK, Spencer AJ, McLaren JE, Ladell K, Lambe T, Milicic A, Price DA, Hill AV, et al. A T cell-inducing influenza vaccine for the elderly: safety and immunogenicity of MVA-NP+M1 in adults aged over 50 years. PLoS One 2012; 7:e48322; PMID:23118984; https://doi.org/10.1371/ journal.pone.0048322.

[112] Oeppen J, Vaupel JW. Demography. Broken limits to life expectancy. Science 2002; 296(5570):1029-31; PMID:12004104; https:// doi.org/10.1126/science.1069675. 